Milivoj Teodorović ${ }^{1}$

Jovan Popesku

Danijel Pavlović ${ }^{3}$
JEL:L83

DOI:10.5937/industrija47-20002

UDC: $338.482: 314(497.11)$

338.487:339.13

Original Scientific Paper

\title{
Perceptual Landscape of the Serbian Domestic Tourism Market
}

\author{
Article history: \\ Received: 24 December 2018 \\ Sent for revision: 28 December 2018 \\ Received in revised form: 8 February 2019 \\ Accepted: 12 February 2019 \\ Available online: 1 April 2019
}

\begin{abstract}
The paper is a demographic analysis of the Serbian domestic tourism market based on the $(n=302)$ survey responses. This paper aims to address the gap in the research literature that points to the perceptual state of domestic tourists in Serbia by conducting a perceptual demographic analysis based on gender, age, occupation and education. The research empirically proves the differences in the perception of domestic tourists about Serbia. The findings indicate mostly a positive image of Serbia as a tourist destination with higher marks given to gastronomy, entertainment, scenery, relaxing and casual atmosphere and hospitality. However, the observation shows that Serbia is not perceived as the first choice for vacation tourism by domestic tourists. Also, the study exposes that the level of education has the most differentiating impact on the perception of Serbia. A gap analysis was conducted using 23 perceptual variables categorized by awareness, quality, image and loyalty. The paper opens the door for further evaluation of the Serbian domestic tourism market and provides direction and the possible basis for the overall development of planning, investment, and marketing strategies.
\end{abstract}

Keywords: gap analysis, domestic tourism market, demographic analysis, Serbia

\footnotetext{
${ }^{1}$ PhD Candidate - Singidunum University, Belgrade, Serbia

2 Singidunum University, Serbia

${ }^{3}$ Singidunum University, Serbia, dpavlovic@singidunum.ac.rs 


\section{Opažajne karakteristike domaće turističke tražnje Srbije}

Apstrakt: Rad je baziran na demografskoj analizi domaćeg turističkog tržišta Srbije korišćenjem $(n=302)$ anketnih uzoraka. Cilj rada je da ukaže na jaz koji se javlja u naučnoj literaturi u vezi sa opažanjima o domaćem turističkom tržištu Srbije uz korišćenje opažajne demografske analize bazirane na polovima, godištu, zanimanju i obrazovanju. Rezultati empirijskog istraživanja ukazuju na razlike u opažanjima domaćih turista o Srbiji kao turističkoj destinaciji. Rezultati ukazuju na pozitivan imidž Srbije kao destinacije domaćeg turizma s tim što je visoko ocenjena gastronomija, kulturno-zabavni život, pejzaži, opuštena atmosfera i gostoprimstvo. Međutim, istraživanje je pokazalo da domaći turisti ne smatraju Srbiju svojim pr izborom za odmor i da nivo obrazovanja ima najjači uticaj na opažanje o Srbiji kao turističkoj destinaciji. Analiza jaza je sprovedena na osnovu 23 promenljive kategorisane prema svesnosti, imidžu, kvalitetu i lojalnosti. Rad otvara mogućnosti za dalja istraživanja u vezi sa domaćim turizmom Srbije i ukazuje na pravac i moguće osnove za unapređenje strategija za razvoj, investiranje i marketing.

Ključne reči: analiza jaza, domaće turističko tržište, demografska analiza, Srbija

\section{Introduction}

For many countries, domestic tourism markets represent an essential part of their economies. Significance of the domestic tourism is apparent in Japan, Mexico, the United Kingdom, the Netherlands, Australia, the United States, Canada, Germany, Italy and Norway where, according to the Organization for Economic Co-operation and Development (OECD, 2018), domestic tourism markets account for up to $70 \%$ of the total tourism market. According to the World Travel \& Tourism Council (WTTC, 2018), the domestic tourism market consumption generated $72.7 \%$ of the global Travel and Tourism GDP in 2017, compared to $27.3 \%$ for tourist exports.

In 2018, global domestic tourism market was expected to grow by $4.1 \%$ to $\$ 4,132.4 \mathrm{bn}$ and increase by $3.9 \%$ annually to $\$ 6,051.5 \mathrm{bn}$ in 2028 , while global inbound tourism is expected to grow by $3.9 \%$ in 2018 to $\$ 1,552.5 \mathrm{bn}$ and increase annually by $4.1 \%$ to $\$ 2,311.4 \mathrm{bn}$ in 2028 (WTTC, 2018). In contrast to the global trends, according to the WTTC Serbia (2018), the Serbian domestic tourism market, in 2017 , contributed $32.2 \%$ to the direct Travel and Tourism GDP, comparing to $67.8 \%$ from the foreign tourist exports. The same report suggests that domestic travel spending is expected to grow by $2.1 \%$ in 2018 to $\$ 716 \mathrm{~m}$ and increase by $3.0 \%$ annually to $\$ 966 \mathrm{~m}$ in 2028. Worldwide domestic tourism market spending represents $70 \%$ of the 
total tourism market and is expected to reach $\$ 6$ tn by 2028 (WTTC, 2018). On the other hand, Serbian domestic tourism spending represents $32 \%$ of the total Serbian tourism market and is expected to become a $\$ 700$ million industry in 2018 (WTTC Serbia, 2018).

According to WTTC Serbia (2018), in 2017, tourism accounted for $6.7 \%$ of Serbia's GDP (direct and indirect contributions), $7.7 \%$ of total exports, and created 96,500 jobs (direct and indirect) or $4.9 \%$ of the total employment. The direct contribution of travel and tourism to the total Serbian GDP in 2017 was $2.3 \%$ which directly supported 39,000 jobs, $1.9 \%$ of the total employment. According to the Statistical Yearbook of the Republic of Serbia (Statistical Yearbook, 2018), in 2017, the number of foreign and domestic tourists who visited Serbia was 1.5 and 1.6 million respectively. The total number of overnight stays was 8.3 million, $62 \%$ of which were by domestic tourists. However, the share of foreign tourism spending was 64\% (WTTC Serbia, 2018). From the total tourists' nights, spas and mountain resorts accounted for $52 \%$, while $38 \%$ of domestic tourists' nights went to spas and $34.1 \%$ to mountain resorts (Statistical Yearbook, 2018). In 2017, the size of the overall Serbian tourism market reached $€ 1.2$ billion euros, where domestic market accounted for $32.2 \%$ (WTTC Serbia, 2018) and is expected to grow by $3.0 \%$ annually by 2028 . The recent rebound of the Serbian domestic tourism market is mostly attributed to the government subsidy program that made domestic tourism services attractive (Ministry of Trade, Tourism and Telecommunications, [MTTT], 2016).

The latest Travel and Tourism Competitiveness Index (TTCI) 2017, places Serbia 95th of 136 countries, behind most of the South East European countries such as Croatia (32), Slovenia (41), Bulgaria (45), Romania (68), Montenegro (72), Macedonia (89) and, just in front of Albania (98) and Bosnia and Herzegovina (113). The report highlights the price competitiveness of the Balkans but points out the weakness of Serbia in air connectivity, international openness and investments in cultural resources (WEF, 2017). Besides many underperforming categories, Serbia needs to significantly upgrade its "soft and hard" infrastructure and improve its regulatory framework (Dwyer, Dragićević, Armenski, Mihalič, \& Knežević Cvelbar, 2014).

The Serbian tourism industry is viewed in the context of the ability to cope with the constant change across the range of key trends such as economic, social, demographic, political, technological and environmental (Nordin, 2005; Yeoman, 2012). The Dwyer's et al. (2014) study emphasizes that those issues are so important that ignoring them by tourism stakeholders will severely impact the competitiveness of the destination. Also, the same authors view destination management as an important factor for creating a framework for the lasting competitive advantage of a destination. Moreover, it suggests that failing to recognize ever-changing customer needs leads to the 
"strategic drift" (Dwyer \& Edwards, 2009) and will inevitably result in a temporary or lasting competitive disadvantage.

According to MTTT (2016), Serbia has a significant potential to become a tourist destination with a high reputation. First, Serbia has human and natural resources, related services and acquired experiences. However, Serbia lacks legal framework, positive investment climate and management practices that are necessary to create a favourable business environment for education, infrastructure, research, innovation, marketing and proliferation of the tourism facilities (Dwyer et al., 2014). Branding of Serbia can be based on several sets of associations including monasteries, villages, spas, English speaking population, and Belgrade as a capital among others (Horwat, 2005; Mihailovich, 2006; Popesku, 2009, 2016, p291).

For many countries, tourism represents almost the entire source of economic output (Maldives, Seychelles, etc.) For those countries, domestic markets are relatively insignificant. However, foreign and domestic tourism markets are a significant source of wealth for developed nations and an economic opportunity for developing countries (OECD Emerging Markets, 2018). Moreover, for most emerging economies, tourism development remains a long-term perspective to a more sustainable future. Europe is the leading global tourism destination with an average growth of arrivals of $5 \%$ in 2017. The exception is the Southern Mediterranean which showed a $13 \%$ increase in tourist arrivals in 2017 (UNWTO, 2018).

Domestic tourism markets balance out the economic growth by maximizing the economic performance throughout periods of crisis. Domestic markets are vital since they generate income, create jobs and extend the off-season utilization of capital resources (Archer, 1978). Therefore, there is a substantial motive for governments, institutions, stakeholders, investors, marketers and local communities to invest and develop the domestic tourism markets (Armenski, Gomezelj, Djurdjev, Đeri, \& Dragin, 2011; Dragićević, Jovičić, Blešić, Stankov, \& Bošković, 2012; Dwyer et al., 2014; Popesku \& Pavlovic, 2013; Teodorović \& Popesku, 2017).

Domestic tourism markets are different from foreign ones. Domestic tourists tend to take advantage of the knowledge and close distance of the domestic destinations and are more demographically diverse since they travel with children, seniors, families and disabled. Also, domestic tourism is attractive to the medium and low-income groups (Deng \& Ritchie, 2016; Pierret, 2011). Domestic tourists also differ in motivations, perceptions and interests. They like to ski, walk, hike, swim, visit mountains, lakes and rivers, enjoy food and music, tour monasteries, culinary events and natural attractions. Similarly, foreign tourists prefer safe destinations and are primarily concerned with having fun and relaxation (Dimitrovski, Todorović, \& Valjarević, 2012). They like to taste local food, experience the local culture, visit landmarks, and 
explore their surroundings. Belgrade and Novi Sad are the Serbian most attractive destinations for international tourists accounting to over $50 \%$ of the international arrivals. Usually, foreign tourists travel with a friend, companion or a group of peers (Deng \& Ritchie, 2016).

The motives of domestic travellers differ from country to county. According to Seckelmann (2002), a large portion of domestic tourists can be attributed to migrant workers visiting friends and relatives. Further, Seckelmann points that besides behaviour there is a significant difference in the prices that domestic and foreign segments pay for the tourism services. Foreign travellers often pay less than domestic counterparts since they buy packages which are priced based on the season, putting domestic tourists into a disadvantage.

Pavlović, Avlijaš \& Stanić (2016) proved that the perception of tourism products is a reliable indicator of destination competitiveness. However, despite past research on the competitiveness of the Serbian tourism and its diverse natural, cultural and man-made resources, the perceptual side of the Serbian domestic tourists, such as awareness, image, quality and loyalty, remains under-researched. Consequently, little is known about the perceptual state of the Serbian domestic tourists and their impact on the demand of the Serbian domestic tourism brand. This creates a gap in the scientific literature on the perceptual side of the domestic Serbian tourists, their motives, beliefs, attitudes, experiences, behaviours and preferences.

The study attempts to highlight these gaps and answer numerous questions on the Serbian perceptual domestic tourism and point to the most important aspects of the Serbian domestic tourists' behaviour. The perceptual aspects, based on the Aaker's (1991) model, categorized by awareness, image, quality and loyalty are important for devising domestic tourism marketing strategies of Serbia.

To address these gaps and to analyse the perceptual structure of the Serbian domestic tourism market, an empirical exploratory study has been conducted using 23 perceptual variables. The principal objective of the study is to explore domestic Serbian tourism market by different demographic categories using perceptual parameters of the awareness, image, quality and loyalty elements in order to reveal the existing trends and opinions of the different Serbian domestic tourism segments.

\section{Literature Review}

Popesku (2016, p.67), suggests that the competitive advantage of a tourism destination reflects a challenging disposition of many human activities which is related to the human, economic and social competitive position of a 
destination. Therefore, it is of the utmost importance that Serbia carves out its own, unique position in the domestic tourism market with a distinct image as a tourist destination. Consequently, Serbia needs to implement focused promotional strategies, develop unique, attractive, competitive and hard to replicate tourism products and services, revitalize image and quality and build domestic tourists' loyalty. Most importantly, Serbia must raise awareness of its natural, cultural, historical potentials and differentiate its position in the region by implementing a powerful destination branding strategy (Dwyer et al., 2014).

However, for the perceptive tourists looking to explore the boundaries beyond the mainstream of the European mass tourism and seek natural scenic attractions, such as mountains, rivers and lakes, or the unique examples of the continent's diverse historical culture and heritage, Serbia has much to offer (Mulec \& Wise, 2013). Serbia offers numerous opportunities for relaxation including a wide variety of spa resorts providing medical and wellness therapies. As a new unexplored destination, Serbia is ideal for soft adventures such as trekking and cycling as well as for its gastronomic and wine tours and other niche market segments (WTTC, 2011).

Kotler \& Keller (2016, p. 97) define perception as the way humans select, organize and interpret external stimuli in order to create a meaningful image of the surrounding world. Boulding (1956) defined image theory as a perception of cognitive, affective and conative elements. Later, Konecnik \& Gartner (2007) established the link between the three elements of the Boulding's image model and the elements of the Aaker's (1991) destination brand equity model (perceived awareness, perceived image, perceived quality and perceived loyalty). Consequently, customer-based or perception-based brand equity approach became the most popular paradigm in the research literature on destination brand equity (Konecnik, et al., 2007; Pike, Bianchi, Kerr, \& Patti, 2010; Myagmarsuren \& Chen, 2011).

Tomić, Marić, Leković, \& Jevtić (2018) emphasize that maintaining long-term loyalty among existing visitors is becoming increasingly difficult. Further, they argue that a loyal customer base is a precondition for long-term profitability. However, according to (Kim \& Chen, 2010), different users have various satisfaction levels, and their behaviour depends on many factors, among others demographic variables such as nationality, age, gender, income, education. These variables are considered significant predictors of tourists' behaviour. Homburg, Fürst, \& Koschate (2010) confirm that gender differences and the level of education influence tourist behaviour.

There are two major reasons for using demographic variables. First, they are easy to measure, and second, they are closely associated with tourists' demands, needs, wants and experiences (Kotler \& Keller, 2016, p117-118). The same authors argue that people tend to change with age. Younger generations prefer tourist destinations that offer adventure, fun, entertainment 
and low prices. On the other hand, middle-aged tourists like destinations that offer excellent service, and different options. Similarly, senior tourists, besides good service, like quiet and less crowded places. Gender is a significant differentiator when it comes to selecting a destination. Perception, attitude and behaviour are different for men and women. Kotler \& Keller (2016, p119) relate gender difference to socialization and genetic composition. Men tend to read more about a destination before selecting one, while women consider tourism destination on a more personal level. However, the roles of men and women are continually changing forcing marketers to adjust their products and services constantly. Next employment segmentation differentiates based on wage and risk while education segmentation is the most pronounced in the areas of sophistication, needs and aspirations.

On the other hand, according to Ranjanthran \& Mohammed's (2010) empirical study the perceived quality, satisfaction, and behaviour have a positive influence on domestic tourism. The same authors suggest that development of the domestic tourism curbs financial outflows from outbound tourism and buying foreign products. The trends of the popularity of domestic tourism could be attributed to seeking better tourism products and experiences at a lower cost, but without sacrifice in satisfaction. Domestic tourism becomes very popular during the holiday season as an opportunity for people to travel and gain new experiences. The first impressions that tourists get about a destination are from the level of direct (lodging and transportation) and indirect (hospitality, interaction with locals) services. While tourists seek to gain more experience in tourism offerings, the efforts should be made to increase the number of attractions but to preserve the old ones as the complementary offerings to ensure the continuity.

Attractiveness of a destination can be viewed through the lens of controllable characteristics (advertising, price, destination offerings and place) and uncontrollable characteristics such as personal traits (Sirgy \& Su, 2000). Specifically, destination environmental characteristics and product offerings have been proved to influence the destination image (Bonn, Joseph, \& Dai, 2005). Under the environmental characteristics or attributes are landscapes, historical attractions, infrastructures, accommodations and facilities which can be used to create a desirable image of a destination. Similarly, different levels of services can be used by tourism managers to alter the destination image in order to cater to the expectations of potential tourists. In addition to altering the destination images to potential visitors, it is important to mention that tourism managers should be aware of existing images in tourists' minds and images that potential travellers have about key competitors (Ahmed, 1991).

The findings of $\mathrm{Wu}, \mathrm{Xie}$, \& Tsai (2015) indicate preference by domestic tourists for tourism destinations that offer interpretation programs and participatory experiences that emphasis theme and design. Tourists prefer to 
see sites that offer traditional themes supported by souvenirs and contemporary exhibitions. Both themes and designs are important attributes of destination attractiveness. Experience through participations causes satisfaction for taking part in preserving the heritage. Researchers agree that many studies on tourist destination focus on the supply side while ignoring visitors' attributes, motivation and preferences. Poria, Butler, \& Airey (2001) indicate lack of papers that explore the relationship between demand perspective and the destinations' core characteristics. The perception of motivations that attract tourists to destinations is under-researched. Therefore, there is a need to better understand tourists' benefits, needs, motivations and experiences from visiting destinations. Pavlovic et al. (2016) argue that attractiveness and accessibility are the perceptual elements of the Serbian domestic destination competitiveness. However, the same authors consider facilities, services and entertainment from the perspective of the Serbian domestic tourist less important.

Branding destination comes with several benefits to tourists such as lower search cost, reduced risk, enhanced value-for-money and perceived experiences, On the other hand, destination brands help communities to elevate tourists' loyalty, become wealthier, experience other cultures, increase employment and develop infrastructure (Aaker, 1991, 1996; Kotler \& Keller, 2012, p280).

\section{Research methodology}

The paper uses gap analysis based on the demographic segmentation of the Serbian domestic tourist market and the perceptual elements of the Aaker's (1991) brand equity model: awareness, image, quality and loyalty. The behaviour analysis is conducted using observable variables.

The exploratory survey is based on the close-end research instrument with the scale from 0 "absolutely no" to 10 "absolutely yes". The choice of such a scale has been made because of the wider variance. Development of the measurement scale of the research instrument was based on the previous research works on tourism destinations (Chekalina, 2015; Im, Kim, Elliot, \& Han, 2012; Konecnik \& Gartner, 2007). The survey data was obtained at the Serbian Tourism Fair 2018 in Belgrade, Serbia in February 2018. The survey resulted in 302 valid responses from individuals that were screened on residency and citizenship. Also, the responses were checked for missing data. According to Hair, Black, Babin \& Anderson (2010) the Cronbach's Alpha test of 0.910 , obtained from the overall data, indicates robust internal consistency. Finally, descriptive statistics analysis is used to check data normality. The 
analysis utilizes mean, median, skewness, kurtosis, maximum and minimum data as the criteria for evaluation.

The survey instrument consisted of the total of 27 questions out of which 23 questions were perceptual variables corresponding to the four elements of the Aaker's customer-based brand equity model: awareness, image quality and loyalty (see Fig. 1). The other four questions are related to demographic variables: age, gender, occupation and education and their corresponding categories (see Table 1).

Fig. 1 Perceptual Variables ( $n=23$ ) Ranked by Mean (Perceptual Variables ( $n=23)$ Ranked by Mean)

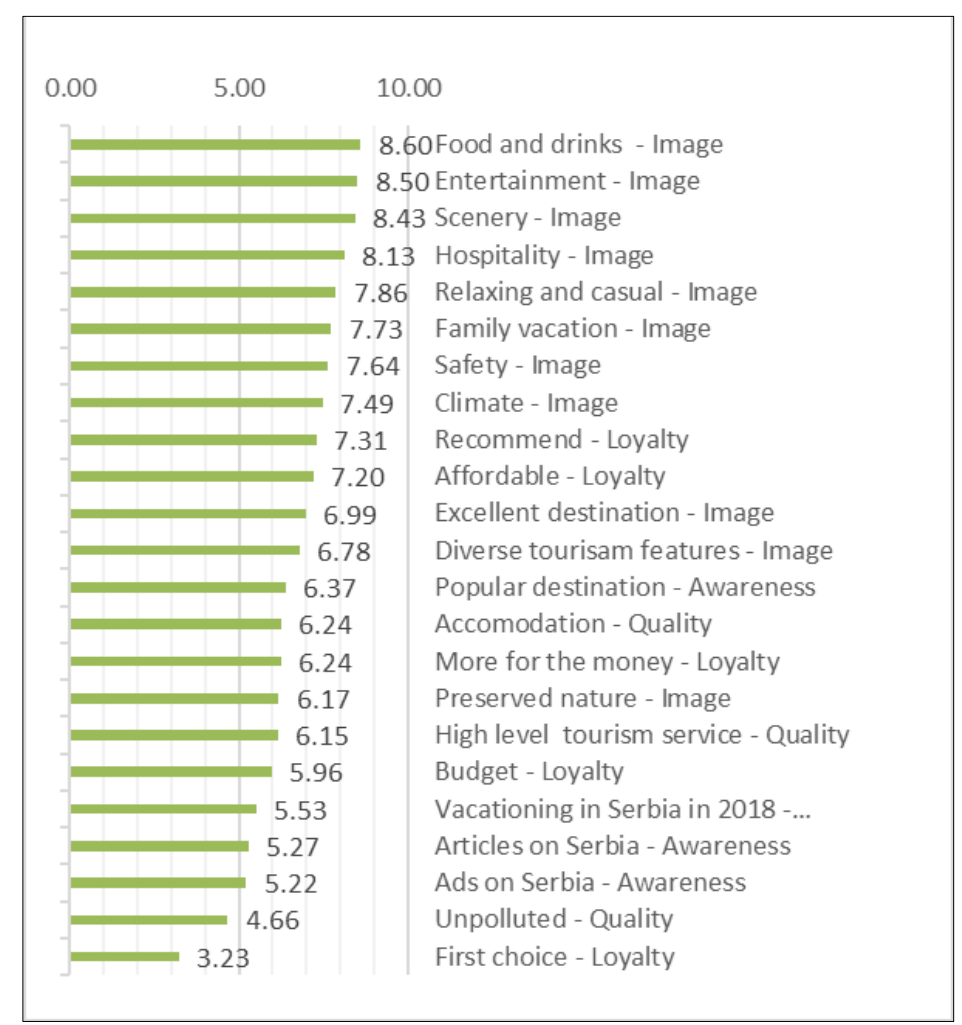

Source: Authors' Research

The mean values are calculated for each of the 23 perceptual variables (see Fig. 1), revealing the most and the least attractive traits. Next, the individual mean values are calculated for each of the 23 perceptual variables by demographic categories (ex. male, female, under 20, public, etc.). Finally, the gap analysis has been conducted on each of the 23 perceptual variables by 
calculating the variance between the maximum and the minimum value by category and for each demographic variable. The analysis shows the level of disagreement between the categories of a related demographic variable by revealing the most important and the least important traits of the Serbian domestic tourism market.

Table 1 Demographic Characteristics

\begin{tabular}{|c|c|c|c|c|c|}
\hline $\begin{array}{c}\text { Socio-demo } \\
\text { Profile }\end{array}$ & Frequency & Percentage & $\begin{array}{c}\text { Socio-demo } \\
\text { Profile }\end{array}$ & Freq. & $\%$ \\
\hline Gender & & & Occupation & & \\
\hline Male & 123 & $40.7 \%$ & Public & 49 & $16.2 \%$ \\
\hline Female & 179 & $59.3 \%$ & Non-gov. & 13 & $4.3 \%$ \\
\hline Total & 302 & $100.0 \%$ & Private & 142 & $47.0 \%$ \\
\hline & & & Other & 98 & $32.5 \%$ \\
\hline Age & & & Total & 302 & $100 \%$ \\
\hline $20-29$ & 117 & $38.7 \%$ & Education & & \\
\hline $30-39$ & 44 & $14.6 \%$ & High school & 64 & $22.2 \%$ \\
\hline $40-49$ & 53 & $17.5 \%$ & Undergrad & 164 & $54.3 \%$ \\
\hline $50-59$ & 39 & $12.9 \%$ & Graduate & 54 & $17.9 \%$ \\
\hline $60+$ & 20 & $6.6 \%$ & PhD & 17 & $5.6 \%$ \\
\hline Total & 302 & $100 \%$ & Total & 302 & $100 \%$ \\
\hline
\end{tabular}

Source: Authors' Research

\section{Results and Discussion}

Demographic analysis shows that most of the respondents (78\%) have an undergraduate or higher degree, while $47 \%$ come from the private sector. On average, a Serbian domestic tourist takes about 6 trips annually which last for 5 days. The females responded in $59.3 \%$ cases while $38.7 \%$ of the respondents were in their 20's (see Table 1). The overall results show that responses range from 8.60 (out of 10.00) for the "food and drinks" to 3.23 (out of 10) for the "Serbia as the first choice", as shown in Fig 1. On the upside, the results show that domestic tourists have in general positive view 6.68 (over 5.0) of Serbia as a tourist destination. Further, the analysis shows that Serbian domestic tourists highly regard food and drinks, entertainment, scenery, hospitality, and casual and relaxing atmosphere but do not consider Serbia as their first choice for a vacation. They regard Serbia as polluted and think that Serbia is under-advertised (see Fig. 1).

Descriptive statistical analysis of the demographic categories shows that data is normally distributed (see Fig. 2). The central tendency of data is confirmed with the mean and median being almost identical. Also, the standard deviation is stable across the categories. However, there are several issues with skewness, kurtosis and minimum values. The negative skewness indicates 
that data distribution is left tailed. The skewness $(-1.33)$ for "PhD" category indicates a possible normality issue.

Fig. 2 Descriptive Statistics Analysis

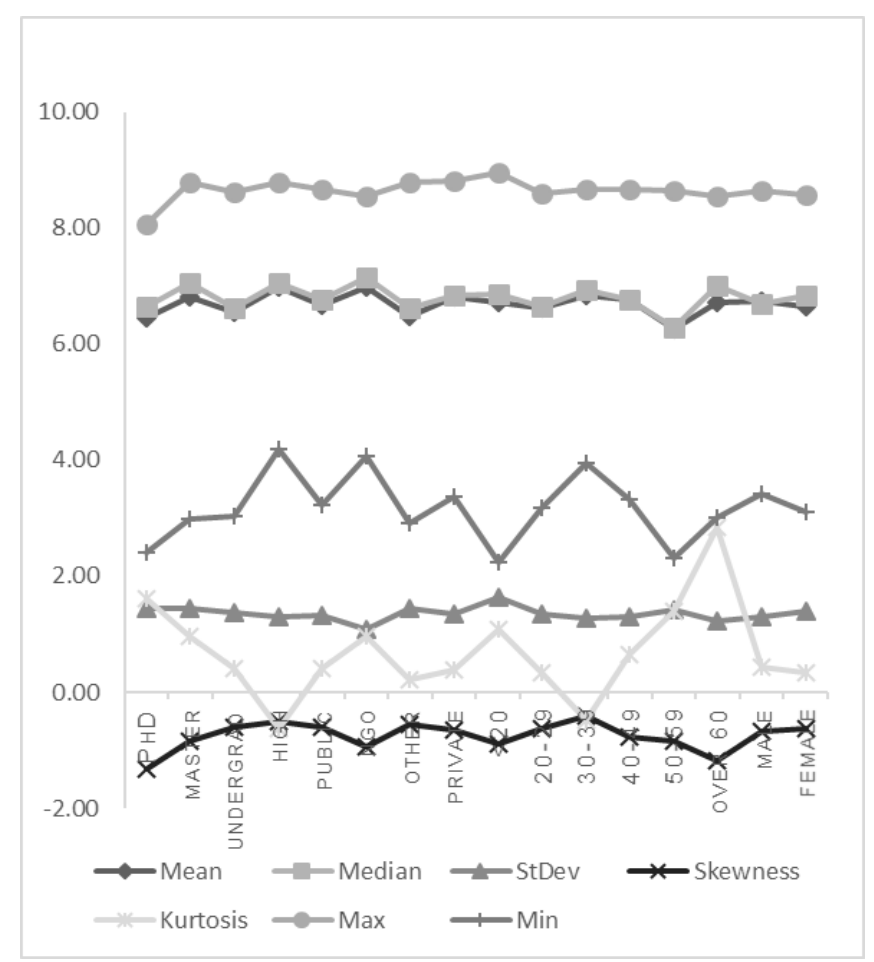

Source: Authors' Research

Next, the kurtosis issue is evident in the value of 2.84 for "over 60 " as well as for "high school', "NGO", and "under 20" categories (see Fig. 2). Another point is that we have high volatility of the minimum perceptual values but very little difference in the responses with maximum values.

Next, the research shows that all top 5 perceptual variables belong to the image while the bottom 5 perceptual variables belong to loyalty, quality and awareness indicating that domestic tourists in Serbia positively respond to the features for which they developed strong associations over time (image) (see Fig.1). In contrast, the research shows that features related to awareness, quality and loyalty such as recall, recognition, top of mind, excellence, recommending, and first choice are not strongly regarded by Serbian domestic tourists as memorable, unique and attractive as the image is (see Fig. 3). 
Teodorović M. et al.: Perceptual Landscape of the Serbian Domestic Tourism Market

Fig. 3 Perceptual Analysis

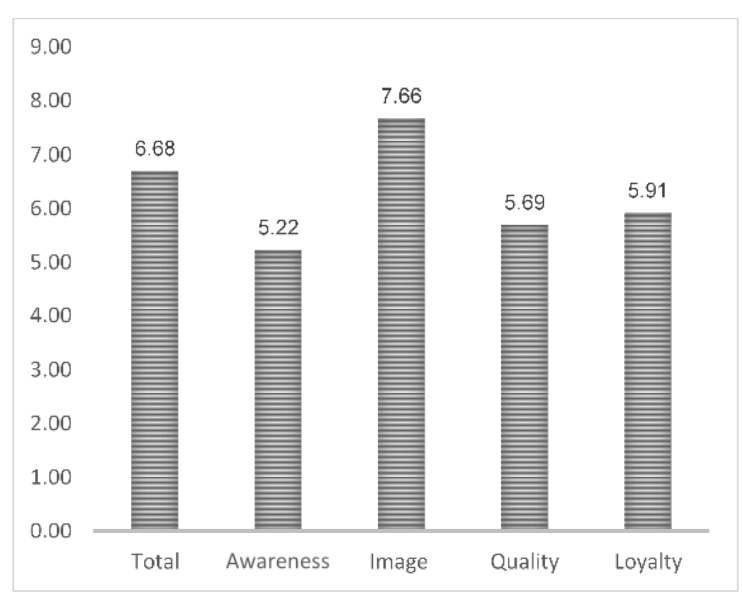

Source: Authors' Research

The research shows that perceptual variables related to the image have above the average perception of the Serbian domestic tourism market while perceptions of the awareness, quality and loyalty have below the average perceptions (see Fig. 3).

Fig. 4 Gender Analysis

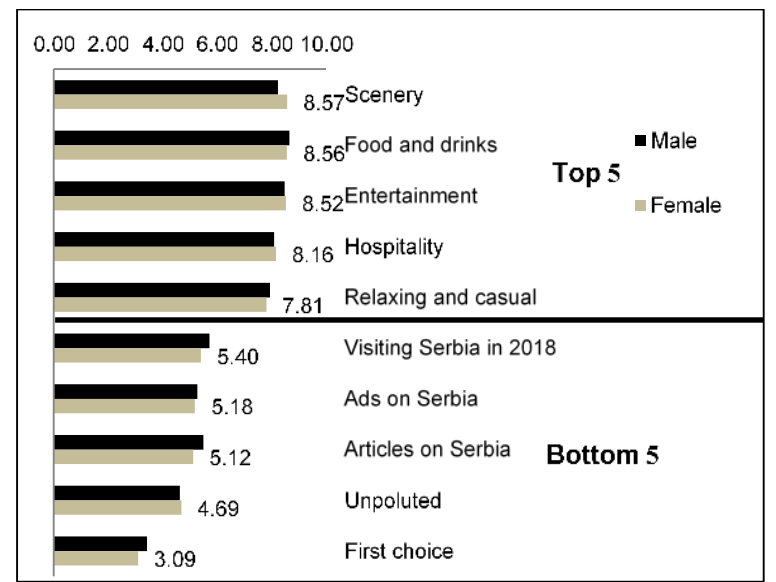

Source: Authors' Research 
This is in line with the previous literature stating that image represents strong and long-lasting associations that reside in the minds of tourists which take time to change in the absence of a significant event (Gartner, 2014).

Further, the study reveals that both males and females have similar perceptions of the Serbian domestic tourism market indicating a harmonious social perceptual structure. Both males and females are happy about scenery, food and drinks, entertainment, relaxed atmosphere and hospitality of the Serbian domestic tourism market but have reservations when it comes to vacation plans, first travel choice, pollution, lack of advertising and articles on Serbia (see Fig. 4).

However, the gap analysis shows that men and women in Serbia disagree on value-for-money, articles on Serbia, first choice, budget and preservation of nature (see Fig. 5). The behaviour responses of males and females are in line with the previous research (Kotler \& Keller, 2016, p119).

Fig. 5 Gender Gap Analysis - Top 5

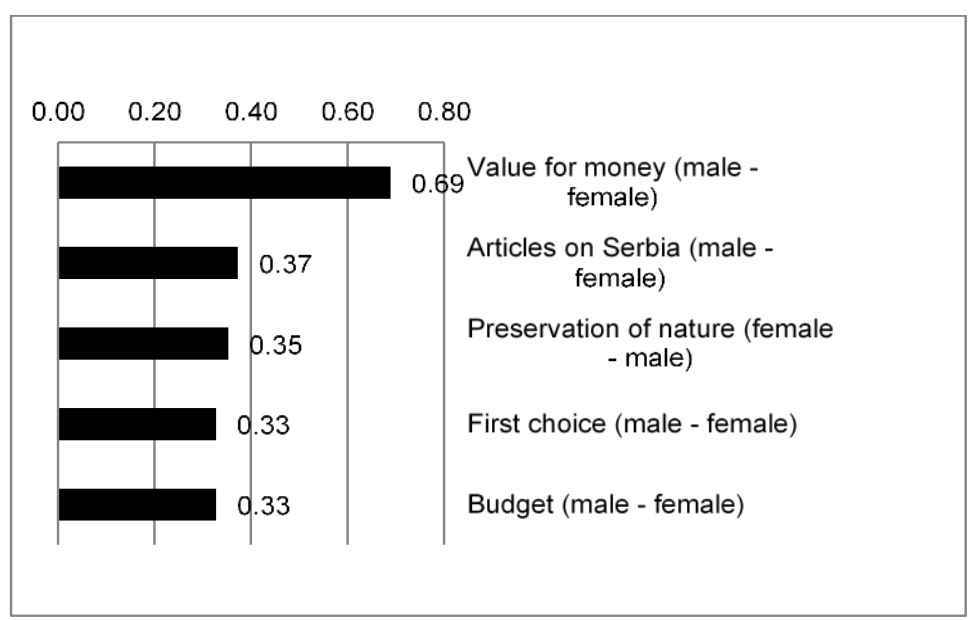

Source: Authors' Research

Among age categories, the highest variances are for the first choice, vacationing in Serbia, ads and articles on Serbia, and recommending Serbia as a tourist destination. The variances in the behaviour of different age categories are supported by the previous literature (Kotler \& Keller, 2016, p118) (see Fig. 6).

The highest disagreement is between millennials and teenagers on "first choice" where millennials give preference to domestic destinations. Also, 
there is a difference in the perception in advertising between "over 60" and "under 20" population. This is expected since younger generations search the internet for information. It was expected that "over 60" and "50-59" segments show similar perceptual levels. Nevertheless, these segments, despite being close, significantly differ on the perception of vacationing in Serbia and advertising of Serbia as a tourist destination. The results show that people from "over 60" segment think that Serbia is under-advertised.

On the other hand, gaps among different occupation categories are even more pronounced (see Fig. 7). The study shows that most disagreements among the occupational categories are in the areas of service, nature, pollution, vacationing in 2018 and articles on Serbia.

Fig. 6 Age Gap Analysis - Top 5

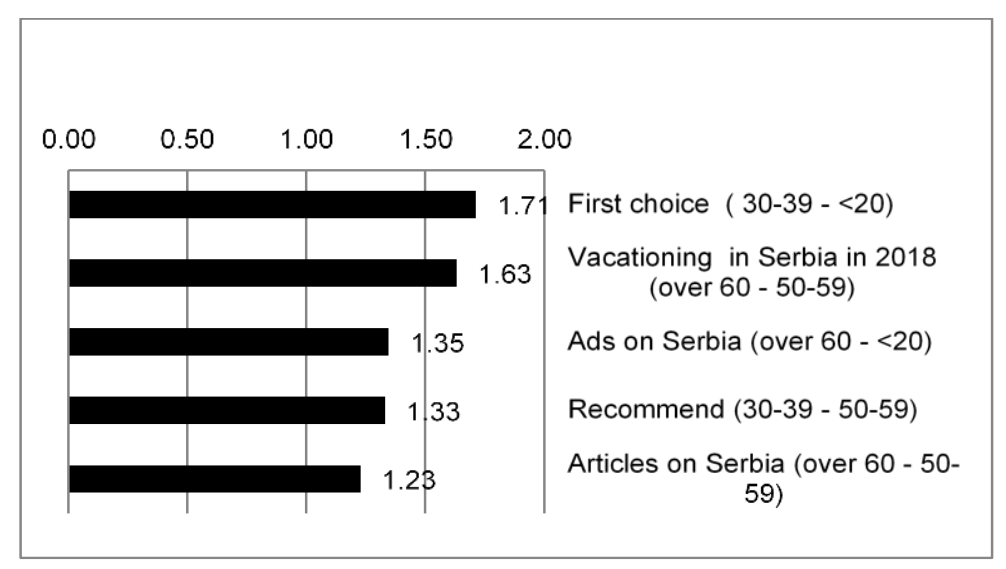

Source: Authors' Research

Further, the analysis shows that the people who work for non-governmental organizations have more positive perceptions of the Serbian domestic tourism than those who work in other sectors (see Fig. 7).

Finally, the results show that the level of education has the most impact on the perception of the Serbian domestic tourism (see Fig. 8). The most significant difference in the perception of the Serbian domestic markets exists in the "articles on Serbia", "preserving nature", "first choice", "vacationing in 2018" and "more-for-money". The highest gap is between the "PhD" and "high school" segments on "articles on Serbia". This is expected since PhD segment tends to read more journals and magazine articles than other segments. However, on the "nature preservation", "first choice", and "vacationing in 2018" the PhD segment scored lower than the other segments. 
Teodorović M. et al.: Perceptual Landscape of the Serbian Domestic Tourism Market

In contrast, the high school segments scored high on "first choice", "vacationing in Serbia" and "more for money".

Fig. 7 Occupation Gap Analysis - Top 5

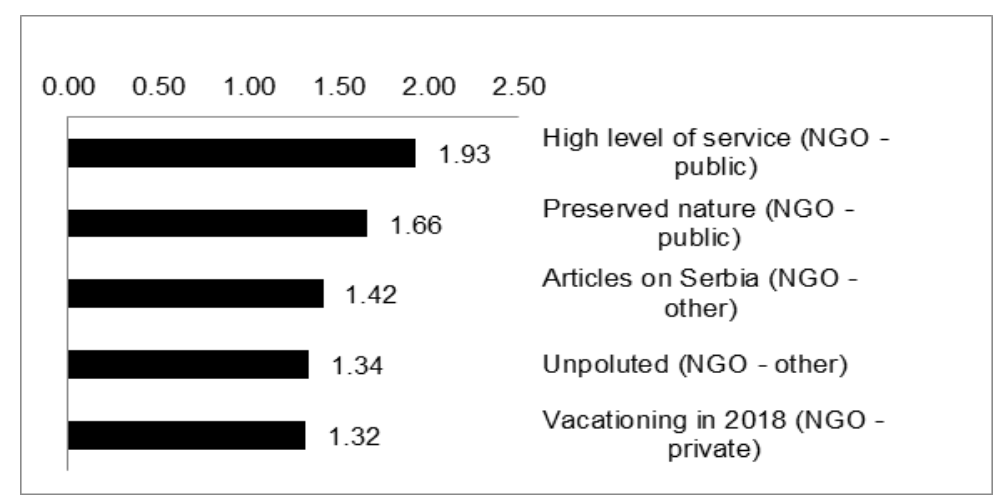

Source: Authors' Research

Fig. 8 Education Gap Analysis - Top 5

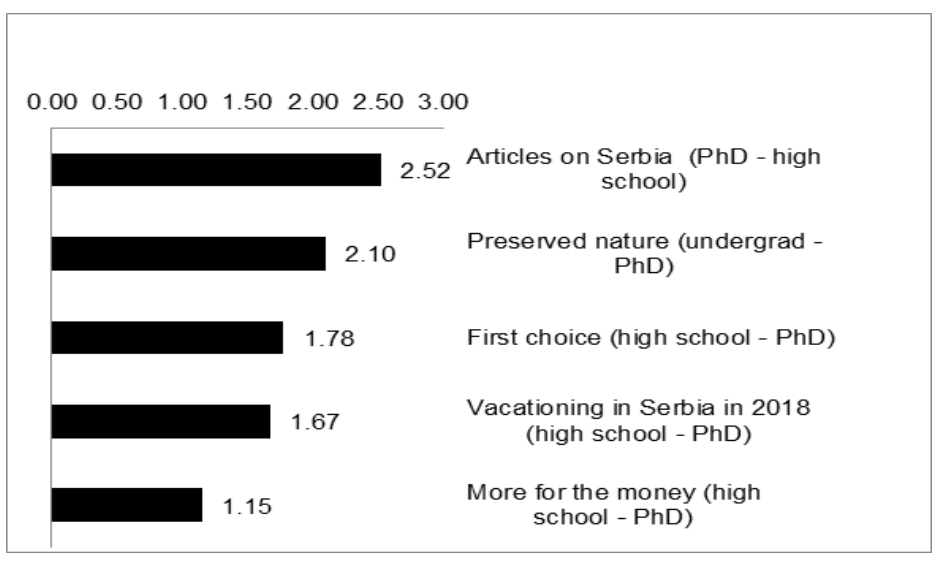

Source: Authors' Research

\section{Conclusion}

The paper empirically proves the differences in the perception of the Serbian domestic tourists about Serbia as a tourist destination. The results create the basis for further measurement of Serbia domestic tourism market perception. This paper defines and uses variables that can be applied in the future 
research to continually measure the perception of domestic tourists. Domestic tourism markets are important because they create jobs, income and utilize the off-season capacities. Domestic tourists differ from the foreign ones in several areas. Domestic tourists benefit from the proximity and knowledge of the domestic destinations, travel more often and are likely to travel with kids, relatives and senior family members. Also, domestic tourists are likely to have moderate income, use their transportation and are interested in hiking, biking, skiing, swimming, gastronomy and entertainment. The study confirms that domestic tourists in Serbia have different perceptions about domestic tourism and a positive opinion on the Serbian domestic market. However, the majority of Serbian domestic tourists do not consider Serbia as their first choice for a vacation; they regard Serbia as polluted and think that Serbia is underadvertised.

The study aimed to examine the perceptual side of Serbian domestic tourists from the perspective of the four demographic variables: gender, age, occupation and education, and from the perspective of the four perceptual variables of the Aaker's (1991) brand equity model: awareness, image, quality and loyalty. The results of the research show that there are differences in the behaviour of Serbian domestic tourists by demographic variables. The gender category shows the least amount of gap of all other categories suggesting that both men and women have very similar perceptions of the Serbian domestic tourism market. The most significant difference in the gender perception is in the "value for money" where men feel they that are getting a bargain. Similarly, women are more positive about "scenery" and "preservation of nature". Slightly higher differences are for the age variable with the highest gap in the first choice, vacationing in Serbia, ads and articles on Serbia, and recommending Serbia as a tourist destination. Somewhat fewer differences are in the perception of diverse offerings, preservation of nature, entertainment, high level of service and destination excellency. The perception by the occupation variable shows even more perceptual differences in service, nature, pollution, vacationing and articles on Serbia and fewer differences on climate, budget, affordability, family destination and scenery. Finally, the research shows that the level of education causes the highest perceptual difference than other demographic variables. The highest gap is in the "articles on Serbia" suggesting a positive correlation between the level of education and the information on Serbia. Also, there is a similar perception about preserving nature. The research shows that climate, safety, the popularity of Serbia, accommodation, affordability, vacationing in Serbia, and selecting Serbia as the first choice are more popular with people with lower levels of education.

From the perspective of the brand equity elements of the Aaker's model (awareness, image, quality and loyalty) the image shows the strongest perception of Serbia as a domestic tourist destination. Next, the perception of 
awareness, quality and loyalty show below average levels of perception. This is in line with the previous literature that supports the theory that the image perspectives are developed over time and are not likely to change unless there is an unforeseen event.

The study is limited by the diversity of the Serbian population. Majority of the respondents, over $70 \%$, have a high level of education while $60 \%$ of the respondents are females. Therefore, we may have some suggestions for further research regarding the quality of data which suggest that further studies with a higher number of responses from the different locations and events in Serbia are needed. Descriptive statistics analysis shows issues regarding skewness and kurtosis suggesting that any conclusions on the category "over 60", "over 20", "PhD", and "high school" should be taken with some caution. Also, the volatility of the minimum values of responses across all demographic categories should be further investigated.

The study reveals a highly complex and diverse perceptual structure of the Serbian domestic tourists suggesting that all activities in the development, investments and marketing geared towards the Serbian domestic tourism market must be factored into the related strategic equations. This means that the promotional strategy must be flexible and diverse enough to target different demographic segments of the Serbian domestic tourism market. At the same time, the promotional strategy must increase the level of awareness, image, quality and loyalty of the Serbian domestic visitors while preserving the integrity and uniqueness of the brand of Serbia as a domestic tourist destination.

Despite its limitations, the study contributes to the research community by revealing the perceptual landscape of the Serbian domestic tourism market and forming the basis for further research on the topic.

\section{References}

Aaker, D. (1991). Managing Brand Equity. New York: The Free Press.

Aaker, D. (1996). Building Strong Brands. New York: Free Press.

Ahmed, Z. U. (1991). The Influence of the Components of a State's Tourist Image on Product Positioning Strategy. Tourism Management, 12 (December), 331340.

Archer, B. H. (1978). Domestic Tourism as a Development Factor. Annals of Tourism Research 5(1), 126-141, DOI:10.1016/0160-7383(78)90007-5.

Armenski, T., Gomezelj, O. D., Djurdjev, B., Đeri, L., \& Dragin, A. (2011). Destination competitiveness: A challenging process for Serbia. Human geographies, 5(1), 19-33. 
Bonn, M. A., Joseph, S. M., \& Dai, M. (2005). International versus Domestic Visitors: An Examination of Destination Image Perceptions. Journal of Travel Research 43(3), 293-301.

Boulding, K. (1956). The Image: Knowledge in Life and Society. Ann Arbor, Michigan: University of Michigan Press.

Chekalina, T. (2015). A Value Co-Creation Perspective on Customer-Based Brand Equity Modelling for Tourism Destinations- A Case from Sweden. Thesis for the degree of Doctor of Philosophy, Östersund 2015. Sweden: Mid Sweden University, SE-831 25 Östersund, Sweden.

Deng, R., \& Ritchie, B. W. (2016). International university students' travel risk perceptions: an exploratory study. Current Issues in Tourism 21(4), 455-476.

Dimitrovski, D. D., Todorović, A. T., \& Valjarević, A. D. (2012). Rural Tourism and Regional Development: Case study of development of rural tourism in the region of Gruča, Serbia. Procedia Environmental Sciences 14, 288-297, https://doi.org/10.1016/j.proenv.2012.03.028.

Dragićević, V., Jovičić, D., Blešić, I., Stankov, U., \& Bošković, D. (2012). Business tourism destination competitiveness: A case of Vojvodina Province (Serbia). Economic Research 25, 311-332.

Dwyer, L., \& Edwards, D. (2009). Tourism product and service innovation to avoid 'strategic drift. International Journal of Tourism Research, 11(4), 321-335.

Dwyer, L., Dragićević, V., Armenski, T., Mihalič, T., \& Knežević Cvelbar, L. (2014). Achieving Destination Competitiveness: An Importance-Performance Analysis of Serbia. Current Issues in Tourism 19 (13), 1309-1336.

Gartner, W. C. (2014). Brand equity in a tourism destination. Place Branding and Public Diplomacy Vol. 00(0), 1-9, DOI:10.1057/pb.20.

Hair, J. J., Black, W., Babin, B., \& Anderson, R. (2010). Multivariate Data Analysis. A Global Perspective. 7th ed. Pearson.

Homburg, C., Fürst, A., \& Koschate, N. (2010). On the importance of complaint handling design: a multi-level analysis of the impact in specific complaint situations. Journal of the Academic Marketing Science, 38, 265-287.

Horwat, C. (2005). Strategija razvoja turizma Republike Srbije- prvi fazni izvestaj. Beograd: Ekonomski fakultet, Mlnistartstvo trgovine, turizma i usluga.

Im, H. H., Kim, S. S., Elliot, S., \& Han, H. (2012). Conceptualizing destination brand equity dimensions from a consumer-based brand equity perspective. Journal of Travel \& Tourism Marketing 29(4), 385-403, DOI:10.1080/10548408.2012.674884.

Kim, J. H., \& Chen, J. S. (2010). The effects of situational and personal characteristics on consumer complaint behaviour in restaurant services. Journal of Travel \& Tourism Marketing, 27(1), 96-112.

Konecnik, M., \& Gartner, W. C. (2007). Customer-based brand equity for a destination. Annals of Tourism Research 34(2), 400-421, DOI:10.1016/j.annals.2006.10.005.

Kotler, P., \& Keller, K. L. (2012). Marketing Management. Upper Saddle River, New Jersey: Pearson Education, Inc.

Kotler, P., \& Keller, K. L. (2016). A Framework for Marketing Management. Sixth Edition, Global Edition. Harlow, England: Pearson.

Mihailovich, P. (2006). Kinship Branding: A Concept of Holism and Evaluation of the Nation Brand. Place Branding 2 (3). 
MTTT. (2016). Tourism Development Strategy of the Republic of Serbia 2016-2025. Belgrade: Government of the Republic of Serbia Ministry of Trade, Tourism and Telecommunications.

Mulec, I., \& Wise, N. (2013). Indicating the competitiveness of Serbia's Vojvodina Region as an of Serbia's Vojvodina Region as an. Tourism Management Perspectives 8, 68-79.

Myagmarsuren, O., \& Chen, C. (2011). Exploring relationships between destination brand equity, satisfaction, and destination loyalty: a case study of Mongolia. Journal of Tourism, Hospitality \& Culinary Arts, 3(2), 81-94.

Nordin, S. (2005). Tourism of tomorrow - travel trends and force of change. ETOUR European Tourism Research Institute.

OECD. (2018). OECD Tourism Trends and Policies 2018. Paris: OECD Publishing.

OECD Emerging Markets. (2018). Business Insights on Emerging Markets 2018. Paris: OECD Emerging Markets Network, OECD Development Centre.

Pavlović, D., Avlijaš, G., \& Stanić, N. (2016). Tourist Perception as Key Indicator of Destination Competitiveness. TEME vol. XL (2), 853-868.

Pierret, F. (2011). Some points on domestic tourism. Retrieved from unwto.org: http://cf.cdn.unwto.org/sites/all/files/elements_on_domestic_tourism.pdf

Pike, S., Bianchi, C., Kerr, G., \& Patti, C. (2010). Consumer-based brand equity for Australia as a long-haul tourism destination in an emerging market. International Marketing Review, 27(4), 434-449, DOI:10.1108/02651331011058590.

Popesku, J. (2009). Destinacijske menadžment organizacije kao oblik upravljanja razvojem turističkih destinacija. Naučni skup sa međunarodnim učešćem Sinergija $2009 \quad$ (pp. 253-256, http://ljig.org/strategija/wpcontent/uploads/sites/2/2014/09/DMO.pdf). Bijeljina: Univerzitet Sinergija .

Popesku, J. (2016). Menadžment turističke destinacije. Beograd: Univerzitet Singidunum.

Popesku, J., \& Pavlovic, D. (2013). Competitiveness of Serbia as a tourist destination: Analysis of selected key indicators. Marketing 44(3), 199-210.

Poria, Y., Butler, R., \& Airey, D. (2001). Clarifying heritage tourism. Annals of Tourism Research, 28(4), 1047-1049.

Ranjanthran, M., \& Mohammed, B. (2010). Domestic Tourism: Perception of domestic tourist on tourism products in Penang Island. Asian Journal OF Management Research 1(2), 795-816.

Seckelmann, A. (2002). Domestic tourism - a chance for regional development in Turkey? Tourism Management 23(1), 85-92.

Sirgy, M., \& Su, C. (2000). Destination Image, Self-Congruity, and Travel Behavior: Toward an Integrative Model. Journal of Travel Research 38 (May), 340-352.

Statistical Yearbook. (2018). Statistical Yearbook of the Republic of Serbia. Belgrade: Statistical office of the Republic of Serbia.

Teodorović, M., \& Popesku, J. (2017). Serbia's competitive position in the regional tourism destination. The European Journal of Applied Economics, Vol 14 No 1,1-12.

Tomić, S., Marić, D., Leković, K., \& Jevtić, J. (2018). Consumers' Propensity to Complain Towards Tourist Agencies' Services: Evidence from Serbia and Croatia. Industrija, Vol.46, No.3, 113-131.

TTCI. (2017). Travel and Tourism Competitive Index 2017. Geneva: World Economic Forum. 
Teodorović M. et al.: Perceptual Landscape of the Serbian Domestic Tourism Market

UNWTO. (2018). Tourism Highlights 2018. Madrid, DOI: https://doi.org/10.18111/9789284419876: World Tourism Organization.

WEF. (2017). The Travel and Tourism Competitiveness Report 2017. Geneva: World Economic Forum.

WTTC. (2011). Serbia Travel \& Tourism Development Potential 2011-23. London: World Travel \& Tourism Council.

WTTC. (2018). The Economic Impact of Travel and Tourism. London: World Travel \& Tourism Council.

WTTC Serbia. (2018). Travel and Tourism Economic Impact 2018 Serbia. London: World Travel \& Tourism Council.

Wu, T.-C., Xie, P. F., \& Tsai, M.-C. (2015). Perceptions of attractiveness for salt heritage tourism: A tourist perspective. Tourism Management 51, December 2015, 201-209.

Yeoman, I. (2012). Tomorrow's Tourism. Bristol, UK: Channel View Publications. 